\title{
ACTIVITY PATTERNS OF SOUTH AMERICAN SILVER CATFISH (Rhamdia quelen)
}

\author{
SCHULZ, U. H. and LEUCHTENBERGER, C. \\ Laboratory of Fish Ecology C2, Universidade do Vale do Rio dos Sinos, CEP 93022-000, São Leopoldo, RS, Brazil \\ Correspondence to: Uwe H. Schulz, Laboratory of Fish Ecology C2, Universidade do Vale do Rio dos Sinos, \\ CEP 93022-000, São Leopoldo, RS, Brazil, e-mail: uwe@unisinos.br \\ Received December 6, 2004 - Accepted February 22, 2005 - Distributed May 31, 2006
}

(With 4 figures)

\begin{abstract}
The South American silver catfish (Rhamdia quelen) is a widely distributed species in Central and South America in areas east of the Andes between Venezuela and the northern parts of Argentina. The bottom dwelling species occurs in lakes and reservoirs as well as in rivers. Between June 2000 and December 2001, sixteen silver catfish were tracked during fourteen 24-h cycles in two-hour-intervals, with the aim of investigating daily movements and habitat use. Covered distances varied between $0 \mathrm{~m} / 2 \mathrm{~h}$ and $326 \mathrm{~m} / 2 \mathrm{~h}$ and the mean distance covered in $2 \mathrm{~h}$ was $25.6 \mathrm{~m}$. The mean activity of individual silver catfish varied between $5.6 \mathrm{~m} / 2 \mathrm{~h}$ and $81.4 \mathrm{~m} / 2 \mathrm{~h}$. The swimming activity was linearly related to the total fish length. The highest mean swimming activity occurred in the morning and at nightfall. Silver catfish concentrated in three areas of frequent use. All of them were characterized by steep banks providing shelter in the form of rip-rap or large woody debris. Vertically, silver catfish preferred the upper $2 \mathrm{~m}$ layer where tracked fish encountered higher temperatures and higher dissolved oxygen concentrations.
\end{abstract}

Keywords: Rhamdia quelen, movement, habitat use.

\section{RESUMO}

\section{Padrões de Atividade do Jundiá (Ramdia quelen)}

O jundiá sul-americano (Rhamdia quelen) é uma espécie amplamente distribuída na América do Sul e Central, ao leste dos Andes e entre a Venezuela e o norte da Argentina. A espécie é um peixe de fundo que ocorre tanto em lagos e reservatórios como em rios. Entre junho de 2000 e dezembro de 2001, 16 jundiás foram monitorados durante 14 ciclos de $24 \mathrm{~h}$, em intervalos de duas h, com o objetivo de investigar movimentos diários e uso de habitat da espécie. Os deslocamentos verificados variaram entre $0 \mathrm{~m} / 2 \mathrm{~h}$ e $326 \mathrm{~m} / 2 \mathrm{~h}$, a distância média medida em $2 \mathrm{~h}$ foi de $25,6 \mathrm{~m}$. A atividade média dos indivíduos oscilou entre $5,6 \mathrm{~m} / 2 \mathrm{~h}$ e $81,4 \mathrm{~m} / 2 \mathrm{~h}$. Os picos de maior atividade ocorreram, principalmente, durante a manhã e no vespertino. Os jundiás se concentraram em três áreas de uso freqüente. Todas as áreas caracterizavam-se por apresentar barrancos muito inclinados com abrigos em forma de seixos grandes ou troncos submersos. Verticalmente a espécie mostrou preferência por profundidades entre $0 \mathrm{~m}$ e $2 \mathrm{~m}$, onde encontravam temperaturas e concentrações de oxigênio mais altas.

Palavras-chave: Rhamdia quelen, movimento, uso de habitat.

\section{INTRODUCTION}

Many aspects of life history of even the best known South American migrating fish species are unknown. Some conventional tagging studies have revealed extreme mobility of some species like dourado (Salminus brasiliensis) or curimata (Prochilodus platensis). In the Uruguay river, dourados were recaptured at a distance of $850 \mathrm{~km}$ from the point of release and curimata $620 \mathrm{~km}$ (Delfino \& Baigun, 1985). Telemetry studies are 
extremely rare, due to infrastructural, funding and safety restrictions in South American countries. Until now, results of only two telemetry studies were published in indexed journals (Mochek et al., 1991; Morais \& Raffray, 1999). Both were carried out in reservoirs. Several studies are underway in the São Francisco, Uruguay, Paraná and Rio dos Sinos rivers. However, published results are not available.

The South American silver catfish (Rhamdia quelen; popular name: jundiá) is a widely distributed species in Central and South America in areas east of the Andes between Venezuela and the northern parts of Argentina (Silvergrip, 1996). It is a bottom dweller which occurs in lakes and reservoirs as well as in rivers. Gomes et al. (2000) reported different growth between sexes: Asymptotic length $\mathrm{L}_{\infty}$ of males was $52.0 \mathrm{~cm}$, of females $66.5 \mathrm{~cm}$, with a maximum weight of $3 \mathrm{~kg}$. The minimum length for sport fishery in the Uruguay river is 30 cm (CARU, 2000). Recently $R$. quelen was quoted as a candidate for aquaculture, substituting exotic species like common carp (Cyprinus carpio) or tilapia, Oreochromis niloticus (Baldisserotto, 2003).

The few existing publications described jundiá as omni- or carnivorous (Gomes et al., 2000). Moreover, the most frequent food items are fish and crustaceans and feeding intensity increases in the autumn and winter (Meurer \& Zaniboni Filho, 1997). Several studies describe jundiá as a predominantly nocturnal species (Winemiller, 1989; Gomes et al., 2000). During the day R. quelen was observed under cover in areas of large woody debris or undercut banks (Casatti \& Castro, 1998).

In the upper Uruguay river spawning activities were most frequent during the spring and tended to continue throughout the year with less intensity (Cassini, 1998). Premature fish performed a lateral migration into the affluents of the main river stem, where final gonadal maturation occurred. The lateral migrations seemed to be triggered by an increase in water temperature and by flood events (Zaniboni Filho \& Schulz, 2003).

The present study was part of a radiotelemetry training program for university students. The objective was to investigate:

- Daily movement patterns; and

- Habitat use of jundiá in a small reservoir.

\section{MATERIAL AND METHODS}

The study was performed in the reservoir of Universidade do Vale do Rio dos Sinos near Porto Alegre, Brazil's southernmost state $\left(29^{\circ} 47,75^{\prime} \mathrm{S}\right.$ and $\left.51^{\circ} 09,47^{\circ} \mathrm{W}\right)$. The total area was 2.7 ha, with extended shallow zones $(28 \%<1 \mathrm{~m})$ and maximum depth of $5.8 \mathrm{~m}$. The riparian vegetation consisted of grass, bush and tree sections. The bathymetry of the reservoir was mapped before the beginning of the tracking experiments.

The jundiás were captured with castnets or by electrical fishing (700 V unpulsed direct current, max. 4 A; EFKO, Germany). The fish were anesthetized (2-phenoxyethanol $350 \mathrm{mg} / \mathrm{L}$ ) and the transmitter was implanted surgically into the peritoneal cavity, according to the procedure described in Adams et al. (1998) with the antenna protruding the body wall about $1.5 \mathrm{~cm}$ posterior to the lateral incision. The antenna was conducted through the body wall by the shielded-needle method with an intravenous catheter (NIPRO medical LTDA; size $16 \mathrm{Gx} 2$ ). The incisions were closed with three stitches of non-absorbable monofilament suture (Ethicon Ethipoint SC-20). The transmitters were standard 10-28 models (Advanced Telemetry Systems, Inc. U.S.A.) of 90 days life span. The transmitter weight never exceeded $2 \%$ of the body weight of the fish.

The surgery was performed in five to eight minutes. Previous tests with dummy implants did not reveal negative effects on tagged individuals (Schulz, 2003).

The study was carried out between June 2000 and December 2001. Sixteen jundiás between a total length of $30.5 \mathrm{~cm}$ and $41.5 \mathrm{~cm}$ and weight between $240 \mathrm{~g}$ and $641 \mathrm{~g}$ were tracked. Between September 2000 and April 2001, the tracking was interrupted due to a receiver failure and necessary maintenance. The interruption caused a lack of tracking data for the summer season (Table 1).

The fish were tracked during $24 \mathrm{~h}$ cycles, monitoring the position of each fish in two hour intervals by boat. Two to eight jundiás were tracked simultaneously. Out of sixteen tagged fish, one expelled the transmitter or died after the surgery. Data of this fish were not considered. For long range localization a loop antenna was used, close range localization was performed acoustically only with the BNC-cable (antenna disconnected). 
TABLE 1

Tracking cycles and tracks per season

\begin{tabular}{|l|c|c|}
\hline Season & $\mathbf{2 4} \mathbf{h}$ tracking cycles (n) & Tracks (number of tracked fish) \\
\hline Fall & 4 & 14 \\
\hline Winter & 7 & 27 \\
\hline Spring & 3 & 12 \\
\hline
\end{tabular}

Previous tests with submersed transmitters showed an accuracy of about $1 \mathrm{~m}$. The position of the boat's stem was considered to be the same as the position of the fish. Numbered buoys were used to mark all identified positions during a 24 cycle. Their coordinates(UTM) were measured with submetrical precision after tracking by a differential GPS (Leica - System 300) and transferred to a digital map of the reservoir (AutoCad Map). During the tracking dissolved oxygen concentrations, the temperature, $\mathrm{pH}$, conductivity, turbidity, and water depth were measured at the position of the fish about $10 \mathrm{~cm}$ above the ground by a multisonde (Hydrolab multiprobe U. S. A.). Additionally, the same parameters were measured in two hour intervals at a $1 \mathrm{~m}$ spaced vertical profile from the surface to ground at the deepest point of the reservoir.

Daily activity patterns were established by measuring the distances between two subsequent positions, referring to meters covered in two hours. When a straight connection between positions included terrestrial areas, the straight connection was substituted by the shoreline. Diel activity patterns and seasonal activity patterns were compared using the non-parametric Friedman test for related samples, hence data were not normally distributed (one sample of Kolmogorov-Smirnov tests). To calculate the linear regression between the mean distance covered during two hours and the total length of the test fish, fish with extraordinary activity levels of more than two times the overall

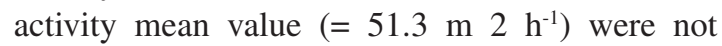
considered. The mean activity during the night (light intensity $<1$ lux) was compared to the mean activity during the day with the Wilcoxon-Rank test. Horizontal and vertical distributions were compared by the chi $^{2}$-test. The significance level for all performed tests was $\mathrm{P}<0.05$.

During winter and spring, high swimming activity levels occurred, which were called excursion phases throughout the test. These excursion phases were defined as the highest 5\% of all ranked activity values, and in this particular study all values were higher than $127 \mathrm{~m} / 2 \mathrm{~h}$.

The areas of intensive use were identified measuring the distance to adjacent nearest positions. If the distance was less than five meters, the point was included. The minimum point number per area was defined as 30 positions.

Since the transmitters did not provide information about the vertical position of the fish in the water column, it was assumed that it was on the ground. Depth values at fish positions were transformed into corresponding depth classes from $0 \mathrm{~m}$ to $5 \mathrm{~m}$ in $1 \mathrm{~m}$ steps. Pairwise comparisons of the mean temperature, dissolved oxygen concentration, conductivity, $\mathrm{pH}$ and turbidity were made between profile and fish positions for each variable and the depth class by the Mann-Whitney U-test as variables were not normally distributed.

\section{RESULTS}

During the fourteen $24 \mathrm{~h}$ tracking cycles, we recorded 652 positions. The covered distances varied between $0 \mathrm{~m} / 2 \mathrm{~h}$ and $326 \mathrm{~m} / 2 \mathrm{~h}$ and the mean distance covered in $2 \mathrm{~h}$ was $25.6 \mathrm{~m}$ (s.d. 44.9).

$56 \%$ of all movements were less than $10 \mathrm{~m}$ (Fig. 1). Activity levels of individual silver catfish were significantly different and varied between

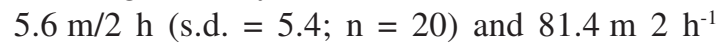
(s.d. $=55.4, \mathrm{n}=12 ; \mathrm{chi}^{2}=54.6$, d.f. $=14, \mathrm{p}<0.001$; Kruskall-Wallis). The swimming activity was linearly related to the total fish length (Fig. 2). Significant differences in movement patterns were detected comparing the mean day $(22.6 \mathrm{~m} / 2 \mathrm{~h}$; s.d. $=43.1 ; \mathrm{n}=360)$ and mean night activities $(29.4 \mathrm{~m} / 2$ h; s.d. $46.8 ; \mathrm{n}=292 ; \mathrm{z}$-value $=-2.26$, $\mathrm{p}=0.024$; Wilcoxon-ranks-test). Covered mean daily distances were not significantly different in the different seasons (spring mean $=31.6 \mathrm{~m} / 2 \mathrm{~h}$, s.d. $=54.5, \mathrm{n}=166$; fall mean $=16.1 \mathrm{~m} / 2 \mathrm{~h}$, 


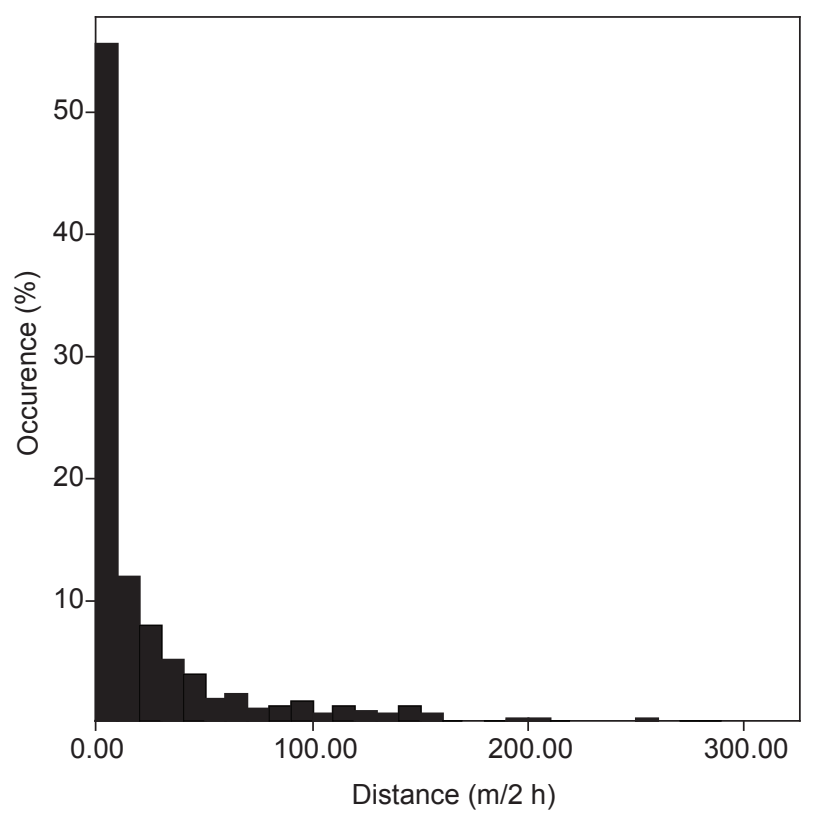

Fig. 1 - Frequency of occurrence of distances covered at two-hour-intervals.

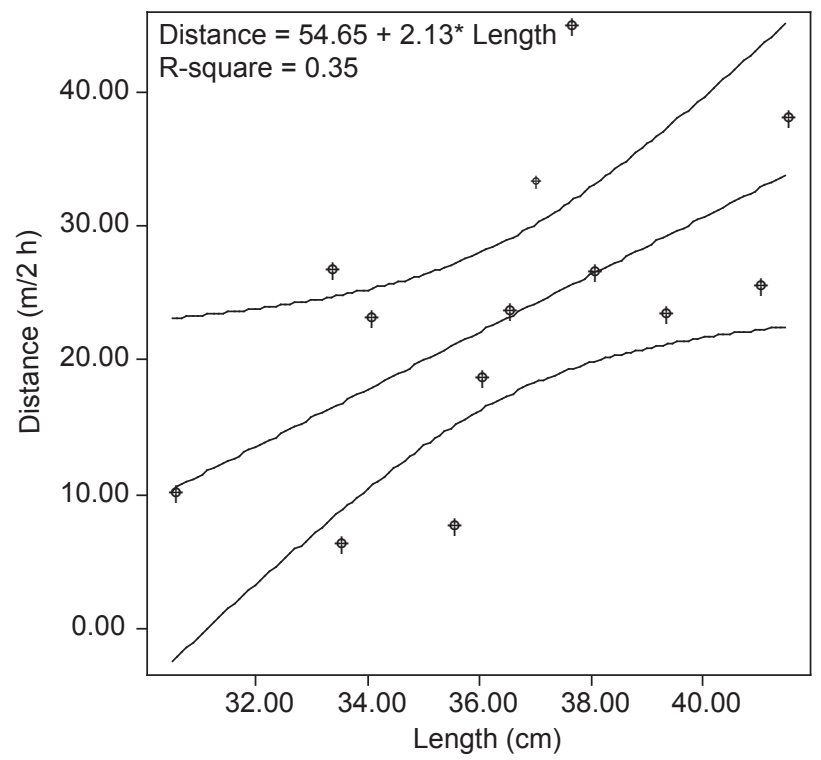

Fig. 2 - Relation between mean distance covered and total length of jundiá with confidence interval 95\% $(\mathrm{p}=0.036)$.

s.d. $=23.1, \mathrm{n}=162 ;$ winter mean $=27.4 \mathrm{~m} / 2 \mathrm{~h}$, s.d. $=47.1, \mathrm{n}=324 ; \mathrm{chi}^{2}=0.7 ;$ d.f. $=2, \mathrm{p}=0.7$; Friedman-test). Fig. 3 displays the overall diel activity pattern of all 15 test fish, which reflects seasonal and individual patterns. The highest swimming activity values occur during the morning and at nightfall. These elevated activity levels are partly caused by excursion phases in winter and spring, which occurred at these hours of the day. Mean distances covered during excursion phases do not differ significantly in the spring and winter $(\mathrm{n}=32, \mathrm{~F}=2.8, \mathrm{p}=0.106$; Student $\mathrm{t}$-test $)$. 


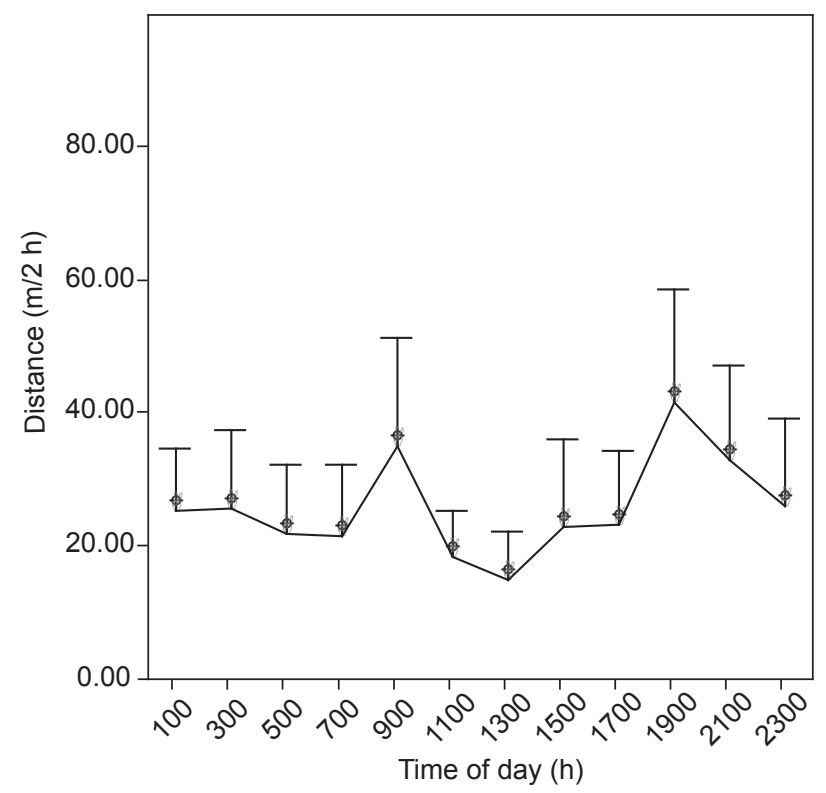

Fig. 3 - Mean diel swimming activity cycle of all 15 jundiá. Vertical bars indicate standard deviation $(n=624)$.

The jundiá were concentrated in three areas of frequent use. Out of 652 positions during the tracking period, 338 were encountered within one of the three areas. The areas measured $34 \mathrm{~m}^{2}(\mathrm{~A})$, $152 \mathrm{~m}^{2}(\mathrm{~B})$ and $175 \mathrm{~m}^{2}(\mathrm{C})$. The $\mathrm{Chi}^{2}$-test reveals that silver catfish were highly selective for these areas $\left(\mathrm{chi}^{2}=402.9\right.$; d.f. $\left.=3 ; \mathrm{p}<0.001\right)$. All of them were characterized by a relatively steep bank, providing abundant shelter in the form of rip-rap (boulders), large woody debris or riparian plant cover. Vertically, jundiá were more frequently located in depths of up to two meters than in deeper waters $\left(\mathrm{chi}^{2}=20.4 ; \mathrm{p}<0.0001\right)$.

When comparing the temperature, dissolved oxygen concentration, conductivity, $\mathrm{pH}$ and turbidity in the profile and at the fish positions, some main differences were observed (Fig. 4): In shallow water (less than $1 \mathrm{~m}$ ) temperature and oxygen concentrations at the fish positions and in the profile did not differ significantly (Table 2). In deeper depths, jundiá chose water layers with warmer temperatures than in the profile. Oxygen concentrations were significantly different in depths lower than $2 \mathrm{~m}$. The jundiá were found in layers with higher oxygen concentrations than in corresponding depths in the profile. Considering $\mathrm{pH}$ in different depths, jundiá constantly chose positions with lower $\mathrm{pH}$ values than the profile. The temperature graph of the $5 \mathrm{~m}$ depth class shows an extremely high confidence interval for fish positions due to a low number of observations in this depth class. The main characteristic of the conductivity and turbidity values are very small confidence intervals at the fish positions. Table 3 shows overall arithmetic means including all depth classes for temperature, dissolved oxygen concentrations, conductivity, $\mathrm{pH}$ and turbidity measured in the vertical profile and at the fish positions. With the exception of the mean conductivity values $(p=0.48)$, all others differed significantly $(\mathrm{p}<0.001$; Mann-Whitneytest), confirming the trend of higher temperatures, oxygen and turbidity and lower $\mathrm{pH}$ values at the fish positions.

\section{DISCUSSION}

A constant concern in radio tracking studies is the possible interference of the tagging method with the behavior. In a previous study, silver catfish were tagged with dummy transmitters intraperitonally. Under controlled conditions in tanks, no differences in growth were detected between a control group and a dummy tagged group (Schulz, 2003). The field experiments of the present study prove the former results. Only one fish out of a total of 17 

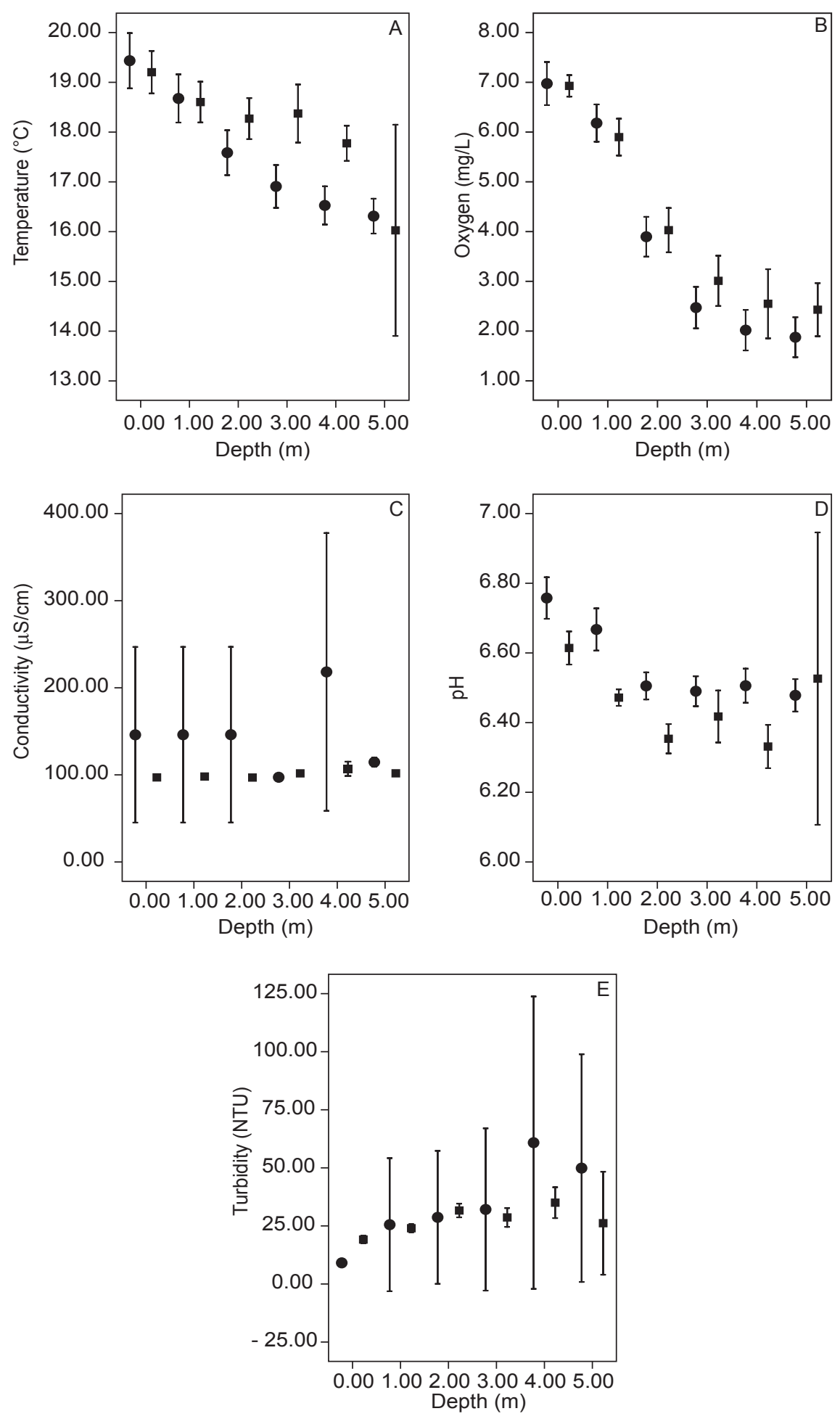

Fig. 4 - Mean temperature (A), oxygen (B), conductivity (C), pH (D), and turbidity (E) in different depths at the fish positions $(\square)$ and in the vertical profile $(\bullet)$. Vertical bars: 95\% confidence intervals 
TABLE 2

Comparison between variables in the profile and at fish positions per depth class. ( $\mathrm{U}=\mathbf{U}$-statistic of Mann Whitney test; and **significant differences: $\mathbf{P}<0.05$ ).

\begin{tabular}{|c|c|c|c|c|c|c|}
\hline $\begin{array}{c}\text { Depth } \\
(\mathbf{m})\end{array}$ & & $\begin{array}{c}\text { Temperature } \\
\left({ }^{\circ} \mathbf{C}\right)\end{array}$ & Oxygen $(\mathbf{m g} / \mathbf{L})$ & $\begin{array}{c}\text { Conductivity } \\
(\mu \mathbf{S} / \mathbf{c m})\end{array}$ & $\mathbf{p H}$ & $\begin{array}{c}\text { Turbidity } \\
(\mathbf{N T U})\end{array}$ \\
\hline 0 & $\mathrm{U}$ & 15011 & 15052 & 13985 & 12243 & 6853 \\
\cline { 2 - 7 } & $\mathrm{P}$ & 0.672 & 0.795 & 0.12 & $0.001^{* *}$ & $<0.0001^{* *}$ \\
\hline \multirow{2}{*}{1} & $\mathrm{U}$ & 14089 & 12732 & 10950 & 8132 & 4106 \\
\cline { 2 - 7 } & $\mathrm{P}$ & 0.974 & 0.146 & $<0.0001^{* *}$ & $<0.0001^{* *}$ & $<0.0001^{* *}$ \\
\hline \multirow{2}{*}{2} & $\mathrm{U}$ & 7127 & 8329 & 7200 & 5100 & 2271 \\
\cline { 2 - 7 } & $\mathrm{P}$ & $0.012^{* *}$ & 0.57 & $0.017^{* *}$ & $<0.0001^{* *}$ & $<0.0001^{* *}$ \\
\hline \multirow{2}{*}{3} & $\mathrm{U}$ & 2806 & 2969 & 3116 & 3229 & 1308 \\
\cline { 2 - 7 } & $\mathrm{P}$ & $0.001 * *$ & $0.004 * *$ & $0.014^{* *}$ & $<0.0001^{* *}$ & $<0.0001^{* *}$ \\
\hline \multirow{2}{*}{4} & $\mathrm{U}$ & 1992 & 1720 & 2630 & 1738 & 756 \\
\cline { 2 - 7 } & $\mathrm{P}$ & $0.011^{* *}$ & $0.001^{* *}$ & 0.719 & $0.001 * *$ & $<0.0001^{* *}$ \\
\hline \multirow{2}{*}{5} & $\mathrm{U}$ & 533 & 241 & 482 & 526 & 520 \\
\cline { 2 - 7 } & $\mathrm{P}$ & 0.618 & $0.005^{* *}$ & 0.363 & 0.579 & 0.99 \\
\hline
\end{tabular}

TABLE 3

Arithmetic Means, standard deviations (= s.d.), maximum and minimum values at the fish positions and in the profile.

\begin{tabular}{|l|c|c|c|c|c|c|c|c|c|c|}
\cline { 2 - 13 } \multicolumn{1}{c|}{} & \multicolumn{2}{c|}{ N } & \multicolumn{2}{c|}{ Mean } & \multicolumn{2}{c|}{ s.d. } & \multicolumn{2}{c|}{ Max. } & \multicolumn{2}{c|}{ Min } \\
\cline { 2 - 12 } \multicolumn{1}{c|}{} & fish & profile & fish & profile & fish & profile & fish & profile & fish & profile \\
\hline Temperature $\left({ }^{\circ} \mathrm{C}\right)$ & 618 & 914 & 18.7 & 17.5 & 2.7 & 3.01 & 28.4 & 28.5 & 12.6 & 12.6 \\
\hline $\mathrm{O}_{2}(\mathrm{mg} / \mathrm{L})$ & 617 & 912 & 5.3 & 3.9 & 2.6 & 3.3 & 14.5 & 18.2 & 0.0 & 0.2 \\
\hline Conductivity $(\mu \mathrm{S} / \mathrm{cm})$ & 618 & 914 & 98.4 & 100 & 12.7 & 18.8 & 192.2 & 310.2 & 36.8 & 70.9 \\
\hline $\mathrm{pH}$ & 616 & 914 & 6.5 & 6.6 & 0.3 & 0.3 & 7.7 & 9.8 & 3.3 & 6.1 \\
\hline Turbidity $(\mathrm{NTU})$ & 614 & 914 & 24.9 & 15.1 & 14.5 & 15.7 & 110 & 302 & 0.5 & 0.2 \\
\hline
\end{tabular}

died or expelled the transmitter after the surgery and was excluded from the data analysis.

In general, catfish are supposed to be predominantly active at night (Wheeler, 1983), although divergent patterns were observed between different species. Tracking African catfish Clarias gariepinus in Lake Ngezi, Zimbabwe, Hocutt (1989) did not observe clear diel patterns. Most radio tagged individuals seemed to be more active during the day. In aquarium experiments, juveniles of the same species were nocturnally active and took $70 \%$ of their daily feeding ration at night. They decreased total feeding activity when food was only offered during the day (Houssain et al., 1999). In a study on shoaling and activity levels of the congeneric catfish Corydoras ambiacus and C. pygmeus, both species were crepuscular, but C. ambiacus showed more activity in the evening, and $C$. pygmeus was more active during the day (Paxton, 1997). In Lagoa dos Quadros, a highly turbid coastal lagoon in south Brazil, juveniles of Loricariichthys anus, a bottom orientated armored catfish species, were more active during the day than at night. High swimming activity levels coincided with high feeding activity (Petry \& Schulz, 2000). However, most references cite catfish as predominantly nocturnal (Hahn et al., 1997, Casatti \& Castro, 1998, Lu \& Peters, 2003). A shift from nocturnal to diurnal behavior can be caused by turbidity. In clear water and in a turbid lake, the European roach (Rutilus rutilus; Cyprinidae) showed higher swimming activities at dawn and dusk and lower activities during the night (Jacobsen et al. 2004). In summer, activity at noon was low in a lake with low turbidity. Fish stayed in areas covered with macrophytes 
forming aggregations and moved into deeper areas during the night. The roach in the turbid lake were dispersed in the pelagial zone during the day and moved inshore at night. The behavior in the clear water lake is seen as a mechanism for predator avoidance. Metcalfe et al. (1999) observed activity patterns of juvenile Atlantic salmon (Salmo salar) under controlled laboratory conditions. Fish activity depended on food availability. Higher food density increased nocturnal activity, although food capture efficiency was lower. Predator avoidance seemed to be mandatory and was supposed to have a more positive impact on fitness than growth. The major predator which occurs in the university reservoir is largemouth bass (Micropterus salmoides), which is visually orientated. Up to turbidity levels of 37 NTU, predation rates of adult black bass were not influenced by impaired vision (Reid et al., 1999). The median turbidity in the university reservoir of 15.1 NTU means optimum predation conditions for black bass. The observed median turbidity value of 24.9 NTU at the tracked fish positions indicates that silver catfish prefer higher turbidity. This behavior together with predominantly nocturnal activity is seen as a mechanism to reduce predation pressure.

Many species show elevated activity at dawn and dusk. In most cases, the increase in activity is related to movements between nocturnal and diurnal habitats. Hohausova et al. (2003) report diel movements between the main river channel and backwaters in river Morava; Lilja et al. (2003) observed migration activities in the main channel of a river in Finland; Schulz \& Berg (1987) detected movements of bream (Abramis brama) between shallow littoral zones of Lake Constance (Germany) and pelagic areas; Baade \& Fredrich (1998) described habitat shifts of Rutilus rutilus in the Spree river (Germany) between the main channel and backwaters. In the case of jundiá, elevated activity levels at dawn and dusk were not caused by habitat shifts, but rather by a more frequent occurrence of excursion phases at these hours of the day.

Excursions are a common phenomenon in radio or ultrasonic tracking studies. Schulz \& Berg (1992), in a study on brown trout (Salmo trutta f. lacustris) movements in Lake Constance, distinguished random movements, which are characterized by zig-zag swimming in a restricted area, from excursions such as sporadic displacements of several kilometers, where tagged fish kept to a certain direction without extensive side movements. Random swimming was interpreted as foraging behavior and excursions as a mechanism to take advantage of temporarily occurring food resources in a patchy distribution pattern. As patchiness of food resources increased in autumn and winter, excursions were more frequent during these seasons of the year. Silver catfish tracked in the present study as well as C. gariepinus (Hocutt, 1989) showed more excursions during the autumn and winter at lower water temperatures, probably as a result of increased patchiness of food resources.

During the present study, larger jundiá moved longer distances. No consistent tendency is available when comparing this result with other studies. Travnichek (2004) tagged different size classes of flathead catfish Pylodictys olivaris in the Missouri river. They showed different dispersal patterns and larger fish moved longer distances. However, Cooke \& McKinley (1999) did not find a significant relationship between the fish length and distances moved in channel catfish (Ictalurus punctatus). Young (1999) found that larger brown trout traveled longer distances and explained this observation by the ability of larger fish to defend or exploit larger diel areas. Additionally, food limitations might have spurred greater traveling during foraging.

Jundiás highly significant preference for two of the three areas of frequent sojourn was caused most likely by the physical underwater structures. Two areas were characterized by the presence of large woody debris or large boulders. These structures provide cover where fish usually stay in periods of rest. Casatti \& Castro (1998) observed silver catfish associated with large woody debris or undercut banks during the day. Rhamdella minuta, a small crepuscular-nocturnal benthic pimelodid catfish, preferred boulders with vegetal detritus and bank structures such as exposed roots or submerse vegetation for shelter (Sazima \& Pombal, 1986; Sabino \& Castro, 1990). The third preferred area was shallow $(<1 \mathrm{~m})$ with overhanging vegetation. Jundiá may have preferred this area because of the shading effect of vegetation, where Hoplias aimara occurred frequently under low water level situations (Morais \& Raffray, 1999) or because of a potential food resource. Abujanra et al. (1999) think that insects falling into the water from overhanging 
vegetation contribute to an essential part of the diet of Pimelodus ortmanni.

$R$. quelen showed a significant preference for depths of up to two meters. In addition to shelter and food availability in these depths, this preference may be caused by temperature and oxygen requirements of the species. Due to the loss of tracking data during the summer, mean temperatures, even in the surface layer of the reservoir, remained lower than $20^{\circ} \mathrm{C}$ throughout the investigated period. Although temperatures in the profile were higher than critical temperatures for R. quelen (Chippari-Gomes et al., 1999), tracked jundiá tended to avoid temperatures below $18{ }^{\circ} \mathrm{C}$. Up to a depth of $2 \mathrm{~m}$, no significant differences were detected between oxygen concentrations in the profile and at fish positions. This may indicate that oxygen concentrations higher than $4 \mathrm{mg} / \mathrm{L}$ do not evoke a positive or negative response. However, for depth ranges lower than $2 \mathrm{~m}$, the differences were significant and the mean concentrations at fish positions were constantly higher than the profile values. This indicates that in conditions lower than $4 \mathrm{mg} / \mathrm{L}$ the silver catfish chose the highest available oxygen concentrations per depth layer. Experiments in aquaculture with channel catfish (Ictalurus punctatus) showed lower mortality and higher production in continuously aerated ponds with oxygen concentrations of $4 \mathrm{mg} / \mathrm{L}$ or higher (Abdalla \& Romaire, 1996). At mean constant dissolved oxygen concentrations of $3.5 \mathrm{mg} / \mathrm{L}$ or less, channel catfish consumed less food and growth was significantly reduced (Carlson et al., 1980). In a small Kansas lake, artificial aeration prevented thermical stratification and hypoxic conditions in depths more than $3 \mathrm{~m}$. This increased oxygen concentrations to $4 \mathrm{mg} / \mathrm{L}$, which had positive effects on the harvest of channel catfish (Mosher, 1983). Unfortunately, published information on oxygen requirements of adult $R$. quelen was not available.

Lopes et al. (2001) found that the ideal $\mathrm{pH}$ range for $R$. quelen is between 8.0 and 8.5. The profile values show that the reservoir is slightly acid and that the optimum $\mathrm{pH}$ range was not available throughout the investigated period. The reason why tracked jundiá constantly chose even lower $\mathrm{pH}$ conditions than measured in the profile needs further research. The observation that the confidence intervals of conductivity and turbidity at fish positions are extremely low is also not well understood. Silver catfish seem to avoid alterations of conductivity and turbidity, whenever possible.

The depth dependent measurements of temperature, $\mathrm{pH}$, oxygen and turbidity may be bias to a certain extent due to the fact that tagged fish were always considered to be on the ground. Consequently, when jundiá were moving during tracking, the position fix may have occurred in "deep" water, but the test fish was swimming in lower layers. This may explain the minimum values shown in Table 3.

Acknowledgments - The authors would like to thank EAWAGDübendorf in Switzerland for the donation of the ATS-receiver and $\mathrm{CNPq}$ and UNISINOS for providing undergraduate scholarships.

\section{REFERENCES}

ABDALLA, A. A. F. \& ROMAIRE, R. P., 1996, Effects of timing and duration of aeration on water quality and production of channel catfish. J. Appl. Aquacult., 6(1): 1-10.

ABUJANRA, F., RUSSO, M. R. \& HAHN, N. S., 1999, Variações espaço-temporais na alimentação de Pimelodus ortmanni (Siluriformes, Pimelodidae) no reservatório de Segredo e áreas adjacentes (PR). Acta Scientiarum, 21(2): 283-289.

ADAMS, N. S., RONDORF, D. W., EVANS, S. D., KELLY, J. E. \& PERRY, R. W., 1998, Effects of surgically and gastrically implanted radio transmitters on swimming performance and predator avoidance of juvenile chinook salmon (Oncorhynchus tshawytscha). Can. J. Fish. Aquat. Sci., 55: 781-787.

BAADE, U. \& FREDRICH. F., 1998, Movement and pattern of activity of the roach in the River Spree, Germany, J. Fish Biol., 52(6): 1165-1174.

BALDISSEROTTO, B., 2003, The emerging silver catfish culture in Latin América. Aquacult. Mag., 29(5): 36-40.

CARLSON, A. R., BLOCHER, J. \& HERMANN, L. J., 1980, Growth and survival of channel catfish and yellow perch exposed to lowered constant and diurnally fluctuating dissolved oxygen concentration. Prog. Fish-Cult., 42(2): 73-78.

CARU (Comisión Administradora de Rio Uruguay), 2000, Resolución 13/00 http://www.caru.org.uy/resolucion1300. htm

CASATTI, L. \& CASTRO, R. M. C., 1998, A fish community of the São Francisco River headwaters riffles, southeastern Brazil. Ichthyol. Explor. Freshwat., 9(3): 229-242.

CASSINI, C. A., 1998, Estrutura da população e distribuição espacial do pintado amarelo, Pimelodus maculatus, do jundiá, Rhamdia quelen e da voga Schizodon aff. nasutus, no alto rio Uruguai, Brasil. Universidade Federal de Santa Catarina, Florianópolis, Master Thesis, 75p.

CHIPPARI-GOMES, A. R., GOMES, L. C. \& BALDISSEROTTO, B., 1999, Lethal temperatures for 
silver catfish, Rhamdia quelen, fingerlings. J. Appl. Aquacult., 9(4): 11-21.

COOKE, S. J. \& MCKINLEY, R. S., 1999, Winter residency and activity patterns of channel catfish, Ictalurus punctatus (Rafinesque), and common carp, Cyprinus carpio L., in a thermal discharge canal. Fish. Manage. Ecol., 6(6): 515-526.

DELFINO, R. \& BAIGUN, C., 1985, Marcaciones de Peces em el Embalse de Salto Grande, Rio Uruguay (Argentina - Uruguay). Rev. Asoc. Cienc. Nat. Litor. St. Tome, 16(1): 85-93.

GOMES, L. C., GOLOMBIESKI, J. L., GOMES, A. R. C., \& BALDISSEROTTO, B., 2000, Biology of Rhamdia quelen (Teleostei, Pimelodidae). Ciência Rural, 30: 179-185.

HAHN, N. S., LESCANO DE ALMEIDA, V. L. \& GRASPAR DA LUZ, K. D., 1997, Alimentação e ciclo alimentar de Hoplosternum littorale (Hankock) (Siluriformes, Callichthyidae) nas lagoas Guaraná e Patos da planície do alto rio Paraná, Brasil. Revta. Bras. Zool., 14(1): 57-64.

HOCUTT, C. H., 1989, Seasonal and diel behaviour of radiotagged Clarias gariepinus in Lake Ngezi, Zimbabwe (Pisces:Clariidae). J. Zool., 219: 181-199.

HOHAUSOVA, E., COPP, G. H. \& JANKOVSKY, P., 2003, Movement of fish between a river and its backwater: diel activity and relation to environmental gradients. Ecol. Freshwat. Fish, 12(2): 107-117.

HOUSSAIN, M. A. R., BATTY, R. S. \& BEVERIDGE, M. C. M., 1999, Diel rhythms of feeding activity in African catfish, Clarias clariepinus (Burchell 1822). Aquacult. Res., 30: 901-905.

JACOBSEN, L., BERG, S., JEPSEN, N. \& SKOV, C., 2004, Does roach behavior differ between shallow lakes of different environmental state? J. Fish Biol., 65: 135-147.

LILJA, J., KESKINEN, T., MARJOMAKI, T. J., VALKEAJARVI, P. \& KARJALAINEN, J., 2003, Upstream migration activity of cyprinids and percids in a channel, monitored by a horizontal split-beam echosounder, Sixth ICES Symposium on Acoustics in Fisheries and Aquatic Ecology (SAFAE). Part 2., 16(3): 185-190.

LOPES, J. M., SILVA, L. V. F., \& BALDISSEROTTO, B., 2001, Survival and growth of silver catfish larvae exposed to different water $\mathrm{pH}$. Aquacult. Int., 9(1): 73-80.

LU, S. L. \& PETERS, E., 2003, Diel and seasonal abundance of fishes in Platte river, Nebraska, USA. Fish. Sci., 69: 154-160.

METCALFE, N. B., FRASER, N. H. C. \& BURNS, M. D., 1999, Food availability and the nocturnal vs. diurnal foraging trade-off in juvenile salmon. J. Anim. Ecol., 68: 371-381.

MEURER, S. \& ZANIBONI FILHO, E., 1997, Habito alimentar do jundiá Rhamdia quelen (Pisces, Siluriformes, Pimelodidae) na região do alto rio Uruguai. Resumos do XII Encontro Brasileiro de Ictiologia, São Paulo, 29.

MOCHEK, A. D., PYANOV, A. I. \& SARANCHOV, S. L., 1991, Results of telemetric tracking of Prochilodus nigricans in a forest river (Peru, Ucayaly department). $J$. Ichthyol., 31: 115-119.
MORAIS, L. T. \& RAFFRAY, J., 1999, Movements of Hoplias aimara during the filling phase of the Petit-Saut dam, French Guyana. J. Fish Biol., 54: 627-635.

MOSHER, T. D., 1983, Effects of artificial circulation on fish distribution and angling success for channel catfish in a small prairie lake. N. Am. J. Fish. Manage., 3(4): 403-409.

PAXTON, C. G. M., 1997, Shoaling and activity levels in Corydoras. J. Fish Biol., 51: 496-502.

PETRY, A. C. \& SCHULZ, U. H., 2000, Ritmo de alimentação de juvenis de Loricariichthys anus (Siluriformes, Loricariidae) da Lagoa dos Quadros, RS, Brasil. Iheringia, Ser. Zool. Porto Alegre, 89: 171-176.

REID, S. M., FOX, M. G., \& WHILLANS, T. H., 1999, Influence of turbidity on piscivory in largemouth bass (Micropterus salmoides). Can. J. Fish. Aquat. Sci., 56(8): 1362 - 1369.

SABINO, J. \& CASTRO, R. M. C., 1990, Alimentação, período de atividade e distribuição espacial dos peixes de um riacho da Floresta Atlântica (Sudeste do Brasil). Revta. Bras. Biol,. 50(1): 23-36.

SAZIMA, I. \& POMBAL JR., J. B., 1986, Um albino de Rhamdella minuta, com notas sobre comportamento (Osteichtyes, Pimelodidae). Revta. Bras. Biol., 49(2): 377-381.

SCHULZ, U. \& BERG, R., 1987, The migration of ultrasonictagged bream, Abramis brama (L.), in Lake Constance (Bodensee-Untersee). J. Fish Biol., 31: 409-414.

SCHULZ, U.H. \& BERG, R., 1992, Movements of ultrasonically tagged brown trout (Salmo trutta L.) in Lake Constance. J. Fish Biol., 40: 909-917.

SCHULZ, U. H., 2003, Effects of surgically implanted dummy transmitters on the South American catfish jundiá (Rhamdia quelen). Braz. J. Biol., 63(2): 345-348.

SILVERGRIP, A. M. C., 1996, A systematic revision of the Neotropical catfish genus Rhamdia(Teleostei, Pimelodidae). Department of Zoology, Stockholm University and Department of Vertebrate Zoology, Swedish Museum of Natural History, Stockholm. (Teleostei, Pimelodidae). PhD Thesis, Department of Zoology, University of Stockholm, Sweden, $156 \mathrm{p}+8 \mathrm{pls}$.

TRAVNICHEK, V. H., 2004, Movements of flathead catfish in Missouri river: Examining opportunities for managing river segments for different fishery goals. Fish. Ecol. Manage., 11(2): 89-96.

WHEELER, A., 1983, Süßwasserfische. Delphin Verlag München, 124p.

WINEMILLER, K. O., 1989, Patterns of variation in life history among South American fishes in seasonal environment. Oecologia, 81(2): 225-241.

YOUNG, M. K., 1999, Summer diel activity and movement of adult brown trout in high-elevation streams in Wyoming. $J$. Fish Biol., 54: 181-189.

ZANIBONI FILHO, E. \& SCHULZ, U. H., 2003, Migratory fishes of the Uruguay River, pp. 157-194. In: J. Carolsfeld, B. Harvey, C. Ross \& A. Baer (eds.) Migratory fishes of South America: Biology, fisheries and conservation status, The International Bank for Reconstruction and Development/The World Bank, Ottawa, Canada. 